ISBN 978-93-84422-79-0

6th International Conference on Humanities, Interdisciplinary Studies, Hospitality and Tourism

Management (HISHTM-17)

Singapore Aug. 10-11, 2017

\title{
The Potential of Gastronomy Tourism in Nong Khai Special Economic Zone
}

\author{
Mallika Jecan $^{\mathrm{a}}$ and Thirachaya Chaikasame ${ }^{\mathrm{a}}$ \\ ${ }^{a}$ Faculty of Business Administration and Accountancy, KhonKaen University, \\ Thailand \\ ipt.mallika@gmail.com
}

\begin{abstract}
The research regarding the potential of gastronomy tourism in Nong Khai Special Economic Zone have the purpose of finding out the feasibility and values of gastronomy tourism in Nong Khai as a tourist and gastronomy resource. The researcher collected the information from the survey, textbooks, articles and other researches previously done on the gastronomy tourism. The results found that Nong Khai have the potential to develop the new, unique and different form of tourism. The tourists have the opportunities to test, including preparing and cooking by themselves. This would allow the tourists to learn firsthand relationships between communities in the province.
\end{abstract}

Keywords: Potential, Gastronomy Tourism

\section{Introduction}

In Northeast Thailand, Nong Khai named as the Nong Khai Special Economic Zone has 200 years long of history and various tourism resources, both cultural and historical. In addition, this province serves as a frontier connecting Thailand to its neighboring countries with similarities of culture and resources, along with the lives of people living in the Mekong River. Those characteristics can be brought to development in compliance with criteria of the UNESECO Creative Cities especially in respect of gastronomy which will provide a choice of tourism and serve as a tool to promote tourism and develop Special Border Economic Zones. Thus, it can be implied that Nong Khai is full of various natural resources, cultural diversity and a variety of lives and local wisdom heritage, i.e. gastronomy (Ministry of Tourism and Sports, 2016). As stated, the alternative tourism derived from its unique feature gastronomy is gastronomic tourism. This form of alternative tourism is consistent with the Twelfth National Economic and Social Development Plan (2560-2564 B.E.) of which goal is to elevate Thailand's economic competitiveness potential with smart farming in modifying production structure of the agricultural sector. It serves as a base of production resources of gastronomic industrial processes and promotes environmental-friendly gastronomic tourism which can promote tourists' traveling experience (Suddan Wisudthiluck et al, 2013). Moreover, in the present era, there is a trend of gastronomic tourism with the aim to increase values of gastronomic-wisdom based products through the new tourism and tourism activities. To this end, gastronomic resources - local cultural heritage- are relied on and used to create innovations towards sustainable tourism.

\section{Purpose of the Study}

1. To investigate situations and analyze the potential of gastronomic tourism in the Nong Khai Special Economic Zone

2. To offer suggestions on the potential of gastronomic tourism in the Nong Khai Special Economic Zone 


\section{Research Methodology}

The present study on the potential of gastronomic tourism in the Nong Khai Special Economic Zone was conducted through the following procedures:

1. The related concepts and prior research were reviewed.

- The potential of tourist attraction have studied the concept of potential and readiness of the 9As tourist site according to the concept of Viwachai Boonyapak (1986), Vipa sriratu (2008) Thammasak Rojanasunthorn (1999), Boonlert Jittangwattana (2005), Ranee Isechaikun (2014), Pimrawee Rojrungsat (2010), Dolruthai Kovatadana (2013), Phayom Thumabut (2006), Buhalis (2000), J. Pelasol (2012)

- Gastronomy Tourism have studied the concept of gastronomy tourism according to the concept of (Timothy \& Wall, 1997; Henderson et al., 2012) (Fathimath, 2009) (Everett \& Aitchison, 2008) (Cohen and Alyson, 2004) (Hsieh \& Chang, 2006) Mac Cannell, 1973; Urry, 1990) (OECD, 2012)

2. The researcher analyzed the collected data qualitatively and then presented the qualitative results in relation to the potential of gastronomic tourism in the Nong Khai Special Economic Zone.

3. Finally, the results were summarized, and the suggestions for future research were provided.

\subsection{The Potential of Gastronomic Tourism in the Nong Khai Special Economic Zone Area contexts of the Nong Khai Special Economic Zone}

Nong Khai with over 200 years of history has a variety of historical and cultural tourism resources, and it is a frontier which connects Thailand to its neighboring countries with similarities of culture and resources, along with the lives of people living in the Mekong River (Ministry of Tourism and Sports, 2016). Its landscape stretches along the Mekong River. Nong Khai is Thailand's upper northeastern border province, and it is a twin town of Vientiane, a capital city of Lao People's Democratic Republic $24 \mathrm{~km}$ far from Nong Khai. The corridor connecting Thailand with Lao is Thai-Lao Friendship Bridge. In addition, this province has Nong Khai customs and immigration office located in Nong Khai Muang District. With all of those features, Nong Khai becomes a door or point of border trading and tourism which can further developed into an export trading center and a base for the agricultural industry (The Nong Khai Provincial Office, 2016). Given that the Mekong River flows through districts almost every with roughly $210.60 \mathrm{~km}$ of territories along the river, it provides the communities with certain agricultural benefits. In particular, civilians living within those territories can use a body of water for agriculture and consumption. Nong Khai is awarded "the world's seventh healthy city" by Modern Maturity, a magazine publisher of the United States of America, of which selection is based on the twelve indicators: climate, cost of living, culture, accommodations, public utility, transportation, medical services, environment, recreation activities, security system, political stability and technologies. Moreover, in promoting its tourism, Nong Khai as a gateway of Indochina and one of the popular tourist attractions is chosen as the Long Stay destination. The potential of the area context of Nong Khai can be developed to support gastronomic tourism in Special Economic Zones.

\subsection{Readiness of Tourist Attractions}

This aspect involves studying readiness of tourist attractions in relation to their suitability for development, changes and tourism attractiveness qualities (Wiwatchai Boonyapak, 1986). The potential of tourist attractions for development is one of the important aspects which should be investigated prior to planning developments or any promotions. To achieve the operational goals and gains, the indicators of the potential of tourist attractions are as follows (Vipa Srirathu, 2008): 1) primary attraction such as location, characteristics of tourist attractions, natural, historical and religious, and human activities 2) complementary factors, including attractiveness of environment, climate, unique landscapes, life and property safety, socio-economic conditions, natural disaster and politics 3) supporting facilities and 4) infrastructure and transportation. 
As mentioned above, It is in line with the composition and availability of tourist attraction. The studied and the concept of potential for tourism can either accommodate tourists or help them to decide where to visit. Although not a direct response to the needs of the traveler, It has had a great influence on the decision to travel to that location. Therefore, the assessment of travel availability (9As) is an improvement of the application of the concept. Ready for tourism (Tourism Department,2015; Ranee Isischaikul, 2014). 1.Attractions (Boonlert Jittangwattana, 2005; Buhalis, 2000; Pike Steven D, 2008; Ranee Ischaikul, 2014; Phayom Thambutr, 2006; Pimravee Rojrungsat,2010). 2.Accessibility (Boonlert Jittangwattana, 2005; Buhalis, 2000; Pike Steven D, 2008; Phayom Thambutr, 2006; Pimrawee Rojrungsat, 2010). 3. Facilities (Boonlert Jittangwattana, 2005; Buhalis, 2000; Pike Steven D, 2008; Ranee Isischaikul,2014; Phayom Thambutr, 2006; Buhalis, 2000; Dolruthai Kovattanakul, 2013). 4.Available packages (Buhalis, 2000; Dolruthai Kovattanakul, 2013). 5. Tourism Activities (Buhalis, 2000; Pike Steven D, 2008; Ranee Isishaikul, 2014). 6. Ancillary service (Buhalis, 2000; Pike Steven D, 2008; Dolrutai Kovattanakul, 2013). 7. Accommodations (Pimrawee Rojrungsat, 2010;Picks Steven D, 2008; Dolrutai Kovattanakul, 2013). 8. Attitude of the community (Attila Pimrawee Rojrungsat, 2010; Dolrutai Kovattananakul). 9. Advertising (Pimrawee Rojrungsat, 2010; Dolrutai Kovattananakul, 2013), which is the development of tourism readiness and facilities as well as the creation of tourism destinations for the special economic zone, Nong Khai Province

\section{Gastronomy tourism}

Gastronomic tourism or gastronomy tourism refers to the relationship between food or beverages and tourism. It can actually be seen from a real instance where people are traveling and communicating for trading; merchants have to visit cities or countries, search for attractive food and beverages differing from their own local and market the found products in their local (Timothy \& Wall, 1997; Henderson et al., 2012). From this point of view, food becomes an attraction for tourism (Fathimath, 2009). Thus, food can be the basic experience which tourists earn from their tourism especially if local food is promoted to be the attraction of destinations along with attractions (Everett \& Aitchison, 2008). According to Cohen and Avieli (2004), food with its own local identity can enhance the recognition of communities, cities, regions or even countries. Hence, visiting places in which local food is sold can help tourists learn culture and earn hands-on experience from the communities in the local areas more effectively than eating in restaurants or hotels. This concept is consistent with the tourists' search for authenticity of experience or exposure to the traditional culture of attractions (Hsieh \& Chang, 2006; MacCannell, 1973; Urry, 1990). Gastronomic tourism, therefore, involves learning about food and serves as an important tool to enhance economic systems of attractions (OECD, 2012).

\section{Conclusion}

The present study examined the concept on the potential of gastronomic tourism of the Nong Khai Special Economic Zone. It particularly focused on the potential and readiness of attractions for gastronomic tourism of the Nong Khai Special Economic Zone. The results demonstrated that the potential and readiness of tourism lay in the determination of attractions and their developments for drawing more tourists. Particularly, the determination of attractions for the development should be based on the goals and indicators of the potential of attractions, especially these following factors: 1) primary attraction, including locations and characteristics of tourist attractions, natural, historical and religious aspects as well as human activities 2) complementary factors, namely attractiveness of environment, climate, unique landscapes, life and property safety, socio-economic conditions, natural disaster and politics 3) supporting facilities 4) infrastructure and transportation. These results are consistent with those on the readiness of attractions. Specifically, on the readiness of attractions, these following factors were the key to defining the attractions' readiness: 1) attractions 2) accessibility 3) amenities 4) available packages 5) activities 6) ancillary services 7) accommodations 8) attitudes and 9) advertising. Hence, the development of the tourism potential and attractions' readiness can be referred to as the improvement of tourism amenities and enhancement of their readiness for generating incomes and creating jobs for a 
community. Moreover, it is involved with promoting social activities and cultural diversity, developing human resources as well as connecting economy, culture and society with technologies.

Considering the above discussions, the potential of tourism and readiness of attractions must be based on tourism resources and local community culture of attractions. It has led to realization that culture is the significant tourism resources. One of the key cultural tourism resources is food. As discussed earlier, the gastronomic tourism establishes the relationship between communities and culture of attractions which have various tourism resources. In addition, this very type of touraism can serve as a tourism activity which promotes tourists' learning experiences by being exposed to the local identity and traditional culture of gastronomic attractions.

Based on the study of the concept and interviews with the involved individuals on the potential of the gastronomic tourism in the Nong Khai Special Economic Zone (Provincial Culture, 2016), the factors of its potential addressed above, namely locations/characteristics of attractions or human activities which can be linked to attractiveness of destinations, were in line with those of the attractions' readiness in respect of attractions, available packages, activities and community attitudes. That is, Nong Khai is a small province adjoining the Mekong River and Laos, so it is possible and convenient to travel to/in the neighboring country in one day. Its water management and landscape system are regulated by building a barrier of a riverbank and a ten-km footpath along the Mekong River starting from Thai-Lao Friendship Bridge to Phra Tat Klang Nam. This very place is developed into a tourist attraction, a place for exercise, fishery and agriculture and a food shop. In summer, Jommanee Beach around the Mekong River is a leisure tourist attraction of Nong Khai which has a number of riverside food stands located under Thai-Lao Friendship Bridge. On this particular beach, tourists can go up the bridge through the entrance under the bridge itself and stroll along. In the early evening, they can commune with nature and scenic beauty along the Mekong River and see the lives of local communities around the Mekong River's attractions whose lives are mainly dependent on the river conforming to the local culture and the nature of agriculture relying on the water resources. The study on such attractions suggests that the gastronomic tourism in Nong Khai is embedded with the lives of people living in the Mekong River where agriculture and inland fishery work becomes more involved in this very tourism. With that involved, the community's diets are influenced by the agriculture. In particular, the agriculture community has connected the gastronomic culture with the community contexts. The diets or food of Nong Khai frequently is vegetables planted by the communities themselves and freshwater fish. On the communities' attitudes towards the tourism, in the Issan community, Issan people are simple, friendly in conformation to the ranking of tourism in Nong Khai at the seventh among healthy tourist attractions, and certain people in the community within Nong Khai are fishermen. This has made us aware of the local consumption which can be brought to improve the capital of the tourism resources.

In addition, the factors of the tourism potential in relation to supporting facilities of Nong Khai's gastronomic attractions conform to those of the attractions' readiness, namely amenities, ancillary services, accommodations and advertising. In the aforementioned attractions, the tourism amenities are ready for tourists; for instance, shops and food stands along the Mekong River sell the products of people in the community, referred to as Nong Khai walking street. Apart from that, the community readily provides tourists with parking lots in many attractions, for example Tha Sadet Market which sells Indochinese products, food and souvenirs. One of the food shops in the market is Dang Hnamnueng; it offers distinctive products which are derived from agriculture in the province. Tourists who use its services can also learn the processes of production through glasses and can park their vehicles in the parking lots provided.

Apart from that, the potential of infrastructure and transportation are also consistent with readiness attractions' accessibility. Nong Kai is located in Special Economic Zones, and it draws a lot of investors' budget and business. According to Special Economic Development Plan, the plan aims to create rural roads network to connect to state highways. In doing so, its transportation has been improved significantly rendering an ease to 
travel to Nong Khai's tourist attractions while infrastructure has been well prepared to welcome domestic and especially foreign tourists.

From the research of potential of gastronomy tourism in the Nong Khai Special Economic Zone, Nong Khai has its potential to providing alternative tourism, i.e. gastronomy tourism. Gastronomy tourism is an alternative tourism, which grants tourists to immerse themselves to local cultural, natural surroundings and local food. In addition, Thai food is worldwide known as one of the best food in the world, so we can harness the power of the name of Thai food to attract foreign tourists to our country. Therefore, in order to welcome tourist, the tourist attraction spots have to have adequate infrastructure, commodity, and comfortable transportation. All in all, alternative tourism as in gastronomy tourism is the new future of Thailand's tourism businesses, in which we have to invest.

\section{Suggestions for Further Studies}

The future studies should focus on the development of gastronomic tourism into the long-life learning center and a new kind of tourism. Moreover, future research should investigate the relationship between the community and the city development to promote the good relationship among the biological diversity and sustainability of the gastronomic tourism.

\section{Acknowledgment}

This article is part of the dissertation on innovative gastronomy tourism development on the base of cultural heritage to the creative city of Nong Khai Province. Faculty of Business Administration and Accounting, Khon Kaen University, Thailand

\section{References}

[1] Boonlert, J. (2005) Sustainable Tourism Development. Bangkok: Tourism Authority of Thailand.

Buhalis, D. (2000). Marketing the Competitive Destination of the Future. Retrieved December 1, 2014, from http://www.wmin.ac.uk/Env/UDP/staff/buhalis.htm.

[2] Cohen, E and Avieli, N. 2004. Food in tourism. Attraction and Impediment. Annals of Tourism Research Vol. 31 (4) Oct 2004: 755-778.

[3] Department of Tourism Ministry of Tourism and Sports Bangkok: Department of Tourism. (2012). Ministry of Tourism and Sports.

[4] Dolrutai, K. (2012) Geography of Thailand that promotes tourism, location, shape, size, boundary, terrain, and the availability of tourist attractions. Tourism Management Faculty of Management, Khon Kaen University Khon Kaen.

[5] Everett, S.; Aitchison, Cara.(2008).The role of food tourism in sustaining regional identity: a case study of Cornwall, South West England.In: Journal of Sustainable Tourism, Vol. 16, No. 2, 2008, p. 150-167.

[6] Hsieh, A. \& Chang, J. (2006). Shopping and Tourist Night Markets in Taiwan. TourismManagement 27 (3): 138-145.

[7] Mac Cannell, D. "Staged Authenticity: Arrangements of Social Spacein Tourist Settings." The American Journal of Sociology,79,3(1973): 589-603

[8] Ministry of Tourism and Sports (2014) National Tourism Development Plan

Searched April 3, 2017, from http://www.tica.or.th/images/plan_tourism2012-2016/2012-2016.pdf

[9] Nong Khai Provincial Cultural Office. (2016). Interview Nong Khai Provincial Cultural Office.

[10] Payom, T. (2003). Bangkok: Institute of Tourism Development for Environmental Conservation, Srinakharinwirot University.

[11] Pimrawee, R. (2010) Community Tourism BANGKOK: O. PRINTING HOUSE. 
[12]Pike, Steven D.(2008).Destination Marketing : anintegrated marketing communication approach. ButterworthHeinmann, Burlington, MA.

[13] Pun-ad, C. (2007) "Introduction to Innovation Management" Bangkok: National Innovation Agency, Ministry of Science and Technology.

[14] Ranee, I. (2015). Nonthaburi: Sukhothai Thammathirat Open University

[15] Ranee, I. 2002. Business Management in Tourism. Nonthaburi: Sukhothai Thammathirat Open University.

[16] Thammasak, R. (1999). Summary of Northern Tourism Development Seminar. Bangkok: Getting toTourism Authority of Thailand.

[17] Timothy J. Dallen.(2011). Cultural Heritage and Tourism. Channel View Publications, 2011. Assistant Professor of Tourism Studies, Arizona State University.

[18] Vipa S. (2008). Ecotourism Potential in Khao Kho, Phetchabun Province.Planning and managing tourism for environmental conservation). Bangkok: Graduate SchoolSrinakharinwirot University.

[19] Wiwatchai, B, (1986). The impact of tourism industry on cultural heritage. PamphletFourth Annual (October Issue): 31-38. 